\title{
Persepsi pengguna gigi tiruan lepasan terhadap fungsi estetik dan fonetik di komunitas lansia Gereja International Full Gospel Fellowship Manado
}

\author{
${ }^{1}$ Joshua D. G. Tulandi \\ ${ }^{2}$ Lydia Tendean \\ ${ }^{3}$ Krista V. Siagian
}

\author{
${ }^{1}$ Kandidat Skripsi Program Studi Pendidikan Dokter Gigi Fakultas Kedokteran \\ ${ }^{2}$ Bagian Biologi Fakultas Kedokteran \\ ${ }^{3}$ Program Studi Pendidikan Dokter Gigi Fakultas Kedokteran \\ Universitas Sam Ratulangi Manado \\ Email: joshua1705@yahoo.com
}

\begin{abstract}
Elderly is the final step of evolution in human life in which the function of oral cavity starts to degrade and impact life, as well as to reduce the aesthetic and phonetic functions. However, the loss of aesthetic and phonetic functions in the elderly stage can be restored by using dentures. This study was aimed to assess the perception about denture aesthetic and phonetic functions among elderly people at International Full Gospel Fellowship Church in Manado. This was a descriptive study with a cross sectional design. There were 73 respondents in this study obtained by using total sampling method and consisted of elderly people who used dentures and agreed to fill the questionnaires. Data were analyzed descriptively and presented in tables. The results showed that based on satisfaction of using denture, the perception of the respondents had the highest score of 361 points (good category). Based on the aesthetic function, the perception of the respondents had the score of 330.3 points (good category); and based on the phonetic function, the perception of the respondents had the score of 334 points (good category). Conclusion: The perception of aesthetic and phonetic functions of dentures among the elderly people at International Full Gospel Fellowship Manado belonged to good category.
\end{abstract}

Keywords: elderly, perception, denture, aesthetics, phonetics

\begin{abstract}
Abstrak: Lansia (lanjut usia) merupakan tahap akhir perkembangan dalam kehidupan manusi dimana mulai terjadinya penurunan fungsi pada rongga mulut yang berdampak pada kehidupan lansia dan penurunan fungsi estetik dan fonetik. Kehilangan fungsi estetik dan fonetik pada lansia dapat dikembalikan dengan pemasangan gigi tiruan. Penelitian ini bertujuan untuk mengetahui persepsi lansia terhadap fungsi estetik dan fonetik gigi tiruan lepasan di komunitas Gereja International Full Gospel Fellowship Manado. Jenis penelitian ialah deskriptif dengan desain potong lintang. Pada penelitian ini digunakan 73 responden yaitu lansia yang memakai gigi tiruan, diperoleh dengan metode total sampling, dan bersedia mengisi kuesioner. Data yang diperoleh diolah secara deskriptif kemudian disajikan berdasarkan distribusi dalam bentuk tabel. Hasil penelitian menunjukkan persepsi lansia berdasarkan kepuasan pada penggunaan gigi tiruan memiliki skor tertinggi yaitu 361 termasuk kategori baik, persepsi lansia berdasarkan fungsi estetik memiliki skor sebanyak 330,3 termasuk kategori baik,dan persepsi lansia terhadap fungsi fonetik sebanyak 334 termasuk kategori baik. Simpulan: Persepsi lansia terhadap fungsi estetik dan fonetik gigi tiruan lepasan di komunitas Gereja International Full Gospel Fellowship Manado termasuk kategori baik.
\end{abstract}

Kata kunci: persepsi, lansia, gigi tiruan, estetik, fonetik 
Lansia merupakan tahap akhir perkembangan dalam kehidupan manusia, seseorang tergolong lansia apabila telah

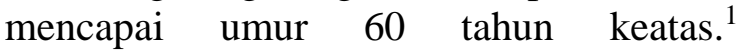
Umumnya pertumbuhan pada manusia akan mencapai hingga tahap ini. Kementerian Kesehatan RI mencatat jumlah penduduk lansia di Indonesia sebesar 18.781 juta jiwa pada dua tahun terakhir, dan akan terus meningkat setiap tahunnya. ${ }^{2}$

Tahap lanjut usia merupakan tahap dimana mulai terjadinya penurunan kemampuan akal dan fisik pada tubuh manusia, begitu pula perubahan di dalam rongga mulut. Seiring dengan bertambahnya usia, terjadi perubahan dalam rongga mulut seperti mukosa mulut yang memutih, epitel yang menipis, gigi yang semakin rapuh, berubah warna, dan tanggal yang sering ditemukan pada lansia. ${ }^{3}$

Kehilangan gigi pada lansia berdampak pada hidupnya yang berakibat penurunan fungsi estetik dan fungsi fonetik. Lansia yang kehilangan gigi terutama pada bagian anterior akan terlihat kurang menarik dan mengalami kesulitan melafalkan beberapa huruf sehingga akan menyebabkan kesulitan berkomunikasi. Pengembalian fungsi estetik dan fonetik yang telah hilang pada lansia dapat dilakukan dengan pemasangan gigi tiruan penuh. ${ }^{4}$

Fungsi estetik mengenai penampilan dari restorasi gigi seperti, warna, dan ukuran gigi. Estetik pada gigi menambah kepercayaan diri lansia dalam bersosialisasi. Estetik dianggap berhasil jika gigi tiruan semakin mirip dengan gigi asli. Keberhasilan pengembalian fungsi estetik pada lansia pengguna gigi tiruan penuh, bergantung pada kerjasama yang baik antar pasien dan dokter. ${ }^{5}$

Gigi tiruan yang mampu mengembalikan fungsi fonetik pada rongga mulut akan memperbaiki pelafalan huruf dan mempermudah komunikasi verbal. Fonetik sangat menentukan hubungan komunikasi lansia dengan orang lain; semakin jelas pelafalan yang diucap semakin baik pula lansia berkomunikasi. ${ }^{6}$
Persepsi adalah pandangan mengenai suatu hal atau objek. Persepsi dalam hubungannya mengenai fungsi estetik dan fonetik pada gigi tiruan yaitu mengenai penilaian terhadap pemenuhan kebutuhan perawatan gigi pada saat menggunakan gigi tiruan. Penilaian yang dilakukan berasal dari pandangan internal, yaitu penilaian berdasarkan pengalaman pribadi individu pengguna gigi tiruan. Persepsi pasien pengguna gigi tiruan akan muncul dari baik atau buruknya fungsi estetik dan fonetik pada rongga mulut setelah pemakaian gigi tiruan. $^{7}$

Penelitian mengenai fungsi estetik dan fonetik sebelumnya pernah dilakukan di Aceh. Dari hasil penelitian tersebut terdapat pasien yang tidak puas dengan terganggunya fungsi estetik dan fonetik. ${ }^{8}$ Penelitian serupa belum pernah dilakukan di Manado. Pada komunitas lansia di Gereja International Full Gospel Fellowship (IFGF) Manado terdapat sebanyak 73 orang lansia pengguna gigi tiruan lepasan yang masih aktif bekerja dan berinteraksi satu dengan lainnya, sehingga pentingnya fungsi estetik dan fonetik harus berperan dengan baik. Berdasarkan latar belakang ini peneliti tertarik untuk mengetahui bagaimana persepsi terhadap fungsi estetik dan fonetik gigi tiruan lepasan pada pengguna gigi tiruan di komunitas lansia Gereja Manado.

\section{BAHAN DAN METODE PENELITIAN}

Jenis penelitian ini ialah deskriptif dengan menggunakan teknik total sampling. Penelitian ini dilaksanakan di Gereja International Full Gospel Fellowship Manado pada bulan Agustus 2016-Januari 2017. Subjek penelitian yaitu anggota komunitas lansia.

Metode pengujian menggunakan 5 poin skala Likert, yaitu: $1=$ tidak setuju, 2 = agak setuju, $3=$ setuju, $4=$ sangat setuju, $5=$ amat sangat setuju. Cara menghitung skor masing-masing pertanyaan yaitu dengan mengalikan jumlah responden yang menjawab sesuai dengan pilihan alternatif jawaban dengan nilai masing-masing alternatif jawaban. Jumlah skor tertinggi 
$73 \times 5=365$ dan jumlah skor terendah $73 \times 1=73$, dengan nilai range 97 . Nilai skala pengukuran yakni mulai dari 73-365, dengan kategori interval penilaian sebagai berikut: $73-171=$ Buruk; 172-268 = Sedang; dan 269-365 = Baik.

\section{HASIL PENELITIAN}

Karakteristik responden dijabarkan menurut jenis kelamin, usia dan jenis pekerjaan (Tabel 1). Responden berjenis kelamin laki-laki berjumlah 26 orang $(35,61 \%)$ dan responden berjenis kelamin perempuan berjumlah 47 (64,39\%).

Distribusi karakteristik responden berdasarkan usia dapat dilihat dari Tabel 2 . Responden yang berusia antara 60-62 tahun berjumlah 71 orang $(97,27 \%)$ dan yang berusia 63 tahun berjumlah 2 orang $(2,73 \%)$.

Tabel 1. Distribusi responden berdasarkan jenis kelamin

\begin{tabular}{lcc}
\hline Jenis kelamin & n & \% \\
\hline Laki-laki & 26 & 35,61 \\
Perempuan & 47 & 64,39 \\
Jumlah & 73 & 100 \\
\hline
\end{tabular}

Tabel 2. Distribusi responden berdasarkan usia

\begin{tabular}{ccc}
\hline Usia & n & \% \\
\hline 60-62 tahun & 71 & 97,27 \\
63 tahun & 2 & 2,73 \\
Jumlah & 73 & 100 \\
\hline
\end{tabular}

Distribusi karakteristik responden berdasarkan jenis pekerjaan dapat dilihat dari Tabel 3. Responden yang bekerja sebagai wiraswasta berjumlah 45 orang $(61,64 \%)$ lebih banyak daripada responden pensiunan berjumlah 28 orang $(38,36 \%)$.

Tabel 3. Distribusi responden berdasarkan jenis pekerjaan

\begin{tabular}{ccc}
\hline Pekerjaan & n & \% \\
\hline Wiraswasta & 45 & 61,64 \\
Pensiunan & 28 & 38,36 \\
Jumlah & 73 & 100 \\
\hline
\end{tabular}

Distribusi karakteristik responden berdasarkan penggunaan gigi tiruan dapat dilihat pada Tabel 4. Responden pengguna gigi tiruan penuh berjumlah 59 orang $(80,82 \%)$ dan responden penguna gigi tiruan sebagian lepasan berjumlah 14 orang $(19,18 \%)$.

Tabel 4. Distribusi responden berdasarkan jenis gigi tiruan

\begin{tabular}{ccc}
\hline Jenis gigi tiruan & n & \% \\
\hline GTP & 59 & 80,82 \\
GTSL & 14 & 19,18 \\
Jumlah & 73 & 100 \\
\hline
\end{tabular}

Distribusi persepsi berdasarkan letak gigi yang hilang ditunjukkan pada Tabel 5 . Anterior RA berjumlah 13 orang $(17,80 \%)$, anterior RB berjumlah 26 orang $(35,61 \%)$, posterior RA berjumlah 10 orang $(13,69 \%)$, posterior RB berjumlah 24 orang $(32,87 \%)$.

Tabel 5. Distribusi persepsi berdasarkan letak gigi yang hilang

\begin{tabular}{lcc}
\hline \multicolumn{1}{r}{ Jawaban } & N & \% \\
\hline Anterior RA & 13 & 17,80 \\
Anterior RB & 26 & 35,61 \\
Posterior RA & 10 & 13,69 \\
Posterior RB & 24 & 32,87 \\
Jumlah & 73 & 100 \\
\hline
\end{tabular}

Distribusi persepsi berdasarkan warna gigi tiruan yang digunakan ditunjukkan pada Tabel 6. Responden amat sangat setuju berjumlah 38 orang $(52,05 \%)$ dan responden sangat setuju berjumlah 35 orang $(47,94 \%)$.

Tabel 6. Distribusi persepsi berdasarkan warna gigi tiruan

\begin{tabular}{lcc}
\hline \multicolumn{1}{c}{ Jawaban } & N & \% \\
\hline Amat sangat setuju & 38 & 52,05 \\
Sangat setuju & 35 & 47,94 \\
Setuju & 0 & 0 \\
Kurang setuju & 0 & 0 \\
Tidak setuju & 0 & 0 \\
Total & 73 & 100 \\
\hline
\end{tabular}

Distribusi persepsi berdasarkan ukuran gigi tiruan ditunjukkan pada Tabel 7 . 
Responden amat sangat setuju berjumlah 47 orang $(64,39 \%)$, responden sangat setuju berjumlah 26 orang $(35,61 \%)$.

Tabel 7. Distribusi persepsi berdasarkan ukuran gigi tiruan

\begin{tabular}{lcc}
\hline Jawaban & N & \% \\
\hline Amat sangat setuju & 47 & 64,39 \\
Sangat setuju & 26 & 35,61 \\
Setuju & 0 & 0 \\
Kurang setuju & 0 & 0 \\
Tidak setuju & 0 & 0 \\
Total & 73 & 100 \\
\hline
\end{tabular}

Distribusi persepsi berdasarkan bentuk gigi tiruan ditunjukkan pada Tabel 8 . Responden amat sangat setuju berjumlah 46 orang $(63,01 \%)$, responden sangat setuju berjumlah 26 orang $(35,61 \%)$, responden setuju berjumlah 1 orang $(1,37 \%)$ dan tidak terdapat responden yang menjawab kurang puas dan tidak puas.

Tabel 8. Distribusi persepsi berdasarkan bentuk gigi tiruan

\begin{tabular}{lcc}
\hline \multicolumn{1}{r}{ Jawaban } & n & \% \\
\hline Amat sangat setuju & 46 & 63,01 \\
Sangat setuju & 26 & 35,61 \\
Setuju & 1 & 1,37 \\
Kurang setuju & 0 & 0 \\
Tidak setuju & 0 & 0 \\
Total & 73 & 100 \\
\hline
\end{tabular}

Distribusi persepsi berdasarkan susunan gigi tiruan ditunjukkan pada Tabel 9. Responden amat sangat setuju berjumlah 48 orang $(65,75 \%)$, responden puas berjumlah 25 orang $(34,24 \%)$.

Tabel 9. Distribusi persepsi berdasarkan susunan gigi tiruan

\begin{tabular}{lcc}
\hline \multicolumn{1}{c}{ Jawaban } & n & \% \\
\hline Amat sangat setuju & 48 & 65,75 \\
Sangat setuju & 25 & 34,24 \\
Setuju & 0 & 0 \\
Kurang setuju & 0 & 0 \\
Tidak setuju & 0 & 0 \\
Total & 73 & 100 \\
\hline
\end{tabular}

Distribusi persepsi berdasarkan penampilan ditunjukkan pada Tabel 10 . Responden amat sangat setuju berjumlah 41 orang $(56,16 \%)$ dan responden sangat setuju berjumlah 32 orang $(43,83 \%)$; tidak ada responden yang menjawab setuju, kurang setuju dan tidak setuju.

Tabel 10. Distribusi persepsi berdasarkan penampilan gigi pada gigi tiruan

\begin{tabular}{lcc}
\hline Jawaban & n & \% \\
\hline Amat sangat setuju & 41 & 56,16 \\
Sangat setuju & 32 & 43,83 \\
Setuju & 0 & 0 \\
Kurang setuju & 0 & 0 \\
Tidak setuju & 0 & 0 \\
Total & 73 & 100 \\
\hline
\end{tabular}

Distribusi persepsi berdasarkan pengucapan huruf yang melibatkan lidah dan gigi depan ditunjukkan pada Tabel 11. Responden amat sangat setuju berjumlah 52 orang $(71,23 \%)$, responden sangat setuju berjumlah 21 orang $(28,76 \%)$; tidak terdapat responden yang menjawab setuju, kurang setuju dan tidak setuju.

Tabel 11. Distribusi persepsi berdasarkan pengucapan huruf (lidah dan gigi depan)

\begin{tabular}{lcc}
\hline \multicolumn{1}{c}{ Jawaban } & n & \% \\
\hline Amat sangat setuju & 52 & 71,23 \\
Sangat setuju & 21 & 28,76 \\
Setuju & 0 & 0 \\
Kurang setuju & 0 & 0 \\
Tidak setuju & 0 & 0 \\
Total & 73 & 100 \\
\hline
\end{tabular}

Distribusi persepsi berdasarkan pengucapan huruf yang melibatkan lidah dan palatum ditunjukkan pada Tabel 12 . Responden amat sangat setuju berjumlah 23 orang $(31,50 \%)$, responden sangat setuju berjumlah 50 orang $(68,50 \%)$; tidak terdapat responden yang menjawab setuju, kurang setuju dan tidak setuju.

Distribusi persepsi berdasarkan pengucapan huruf yang melibatkan bibir dan gigi depan ditunjukkan pada Tabel 13 . Responden amat sangat setuju berjumlah 
28 orang $(38,35 \%)$, responden sangat setuju berjumlah 45 orang $(61,64 \%)$; tidak terdapat responden yang menjawab setuju, kurang setuju dan tidak setuju.

Tabel 12. Distribusi persepsi berdasarkan pengucapan huruf (lidah dan palatum)

\begin{tabular}{lcc}
\hline \multicolumn{1}{r}{ Jawaban } & n & \% \\
\hline Amat sangat setuju & 23 & 31,50 \\
Sangat setuju & 50 & 68,50 \\
Setuju & 0 & 0 \\
Kurang setuju & 0 & 0 \\
Tidak setuju & 0 & 0 \\
Total & 73 & 100 \\
\hline
\end{tabular}

Tabel 13. Distribusi persepsi berdasarkan pengucapan huruf (bibir dan gigi depan)

\begin{tabular}{lcc}
\hline Jawaban & n & \% \\
\hline Amat sangat setuju & 28 & 38,35 \\
Sangat setuju & 45 & 61,64 \\
Setuju & 0 & 0 \\
Kurang setuju & 0 & 0 \\
Tidak setuju & 0 & 0 \\
Total & 73 & 100 \\
\hline
\end{tabular}

Distribusi persepsi berdasarkan gigi tiruan tidak menyebabkan gangguan ketika berbicara ditunjukkan pada Tabel 14. Responden amat sangat setuju berjumlah 47 orang $(64,39 \%)$, responden sangat setuju berjumlah 26 orang $(35,61 \%)$, dan tidak terdapat responden yang menjawab setuju, kurang setuju dan tidak setuju.

Tabel 14. Distribusi persepsi berdasarkan gangguan ketika berbicara

\begin{tabular}{lcc}
\hline \multicolumn{1}{c}{ Jawaban } & n & \% \\
\hline Amat sangat setuju & 47 & 64,39 \\
Sangat setuju & 26 & 35,61 \\
Setuju & 0 & 0 \\
Kurang setuju & 0 & 0 \\
Tidak setuju & 0 & 0 \\
Total & 73 & 100 \\
\hline
\end{tabular}

Distribusi persepsi berdasarkan pelafalan setiap kali berbicara ditunjukkan pada Tabel 15. Responden amat sangat setuju berjumlah 48 orang $(65,75 \%)$, responden sangat setuju berjumlah 25 orang $(34,24 \%)$; tidak terdapat responden yang menjawab setuju, kurang setuju dan tidak setuju.

Tabel 15. Distribusi persepsi berdasarkan pelafalan saat berbicara

\begin{tabular}{lcc}
\hline Jawaban & n & \% \\
\hline Amat sangat setuju & 48 & 65,75 \\
Sangat setuju & 25 & 34,24 \\
Setuju & 0 & 0 \\
Kurang setuju & 0 & 0 \\
Tidak setuju & 0 & 0 \\
Total & 73 & 100 \\
\hline
\end{tabular}

Hasil penilaian skor rata-rata pada dimensi persepsi tentang fungsi estetik yaitu 335 dan nilai tersebut termasuk pada kategori baik, dengan alternatif jawaban yang paling banyak dipilih responden yaitu amat sangat setuju dan sangat setuju (Tabel 16). Hasil penilaian yang diperoleh secara kontinum dapat dilihat pada Gambar 1.

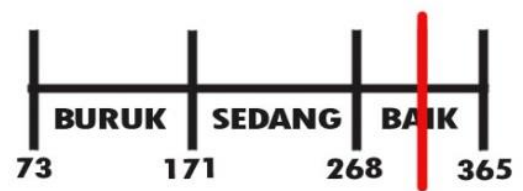

Gambar 1. Skor dimensi fungsi estetik

Hasil penilaian skor rata-rata pada dimensi persepsi tentang fungsi fonetik yaitu 334 dan nilai tersebut termasuk pada kategori baik dengan alternatif jawaban yang paling banyak dipilih responden yaitu sangat puas sampai cukup puas (Tabel 17). Hasil penilaian yang diperoleh secara kontinum dapat dilihat pada Gambar 2.

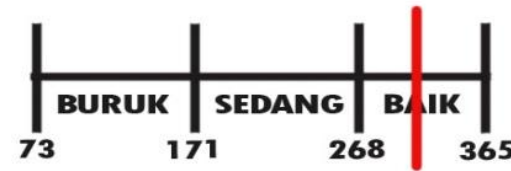

Gambar 2. Skor dimensi fungsi fonetik 
Tulandi, Tendean, Siagian: Persepsi pengguna gigi tiruan lepasan terhadap ...

Tabel 16. Distribusi penilaian berdasarkan fungsi estetik

\begin{tabular}{clcccccc}
\hline No & Dimensi fungsi estetik & ASS & SS & S & KS & TS & Skor \\
\hline 1 & Warna gigi tiruan & 190 & 140 & 0 & 0 & 0 & 330 \\
2 & Ukuran gigi tiruan & 235 & 104 & 0 & 0 & 0 & 339 \\
3 & Bentuk gigi tiruan & 230 & 104 & 3 & 0 & 0 & 334 \\
4 & Susunan gigi tiruan & 240 & 100 & 0 & 0 & 0 & 340 \\
5 & Gigi tidak mengganggu penampilan & 205 & 128 & 0 & 0 & 0 & 333 \\
\hline Total & & & & & & 1676 \\
Rerata & & & & & & 335 \\
\hline
\end{tabular}

Tabel 17. Distribusi penilaian berdasarkan fungsi fonetik

\begin{tabular}{|c|c|c|c|c|c|c|c|}
\hline No & Dimensi fungsi fonetik & ASS & SS & $\mathbf{S}$ & KS & TS & Skor \\
\hline 1 & Pengucapan melibatkan lidah dan gigi depan & 260 & 84 & 0 & 0 & 0 & 344 \\
\hline 2 & Pengucapan melibatkan lidah dan palatum & 115 & 200 & 0 & 0 & 0 & 315 \\
\hline 3 & Pengucapan melibatkan bibir dan gigi depan & 140 & 180 & 0 & 0 & 0 & 320 \\
\hline 4 & Gangguan saat berbicara & 235 & 104 & 0 & 0 & 0 & 339 \\
\hline 5 & Pelafalan jelas & 240 & 100 & 0 & 0 & 0 & 340 \\
\hline \multicolumn{2}{|c|}{ Total } & & & & & & 1658 \\
\hline \multicolumn{2}{|c|}{ Rerata } & & & & & & 331 \\
\hline
\end{tabular}

\section{BAHASAN}

Berdasarkan hasil penelitian yang dilakukan terhadap 73 responden komunitas lansia Gereja IFGF Manado tentang fungsi estetik dan fonetik gigi tiruan didapatkan karakteristik responden pengguna gigi tiruan berdasarkan jenis kelamin menunjukkan bahwa dengan jenis kelamin laki-laki $(35,61 \%)$ lebih sedikit daripada responden perempuan $(64,39 \%)$ (Tabel 1). Hal ini selaras dengan hasil penelitian yang dilakukan Agniti ${ }^{9}$ pada tahun 2010 tentang persentase pemakaian gigi tiruan di Indonesia yang mendapatkan bahwa pengguna gigi tiruan berjenis kelamin perempuan lebih banyak dibandingkan dengan laki-laki.

Data karakteristik responden berdasarkan usia mendapatkan sebagian besar responden $(97,27 \%)$ berusia $60-62$ tahun dan hanya 2 responden saja $(2,73 \%)$ yang berusia 63 tahun (Tabel 2). Pengguna gigi tiruan banyak terdapat pada lansia yang karena lansia mengalami perubahan alami pada rongga mulut seiring bertambahnya usia dan akan menimbulkan masalah sejalan dengan hilangnya gigi asli. ${ }^{10}$

Data karakteristik responden berdasarkan pekerjaan memperlihatkan bahwa sebagian besar responden $(61,64 \%)$ masih memiliki pekerjaan sebagai wiraswastawan dan hanya 28 responden $(38,36 \%)$ sebagai pensiunan (Tabel 3). Hal ini menunjukkan responden yang menggunakan gigi tiruan dalam pekerjaan sehari-hari lebih banyak daripada yang sudah tidak bekerja. Aktif bekerja tentunya akan selalu membutuhkan komunikasi. Responden yang menggunakan gigi tiruan merasa lebih percaya diri dan lebih nyaman berinteraksi dengan orang lain. Kegunaan gigi tiruan tentunya akan mengembalikan fungsi estetik dan fonetik yang sempat terganggu. Menggunakan gigi tiruan berarti membutuhkan biaya. Umumnya semakin tinggi kedudukan sosial seseorang akan lebih besar tuntutannya terhadap faktor estetik. ${ }^{11}$

Persepsi mengenai jenis gigi tiruan yang digunakan mendapatkan sebanyak 59 responden $(80,82 \%)$ menggunakan GTP dan 14 responden $(19,18 \%)$ menggunakan GTSL (Tabel 4). Pada usia lansia akan banyak ditemui pasien yang menggunakan GTP daripada GTSL hal ini dikarenakan jumlah gigi yang berkurang akan jauh lebih banyak pada usia 60 hingga 65 tahun. ${ }^{12}$

Persepsi mengenai letak gigi tiruan yang hilang mendapatkan responden yang kehilangan gigi anterior RA berjumlah 13 orang $(17,80 \%)$, yang kehilangan gigi 
anterior RB berjumlah 26 orang $(35,61 \%)$, yang kehilangan gigi posterior RA berjumlah 10 orang $(13,69 \%)$, dan yang kehilangan gigi posterior RB berjumlah 24 orang $(32,87 \%)$ (Tabel 5). Kehilangan gigi RB lebih banyak ditemukan dibanding dengan kehilangan gigi RA; hal ini dapat memengaruhi gerak pada mulut. ${ }^{12}$

Hasil persepsi pengguna gigi tiruan berdasarkan warna memperlihatkan bahwa responden yang merasa amat sangat setuju sebanyak 38 orang $(52,50 \%)$ dan 35 responden $(47,94 \%)$ sangat setuju (Tabel 6). Hal ini menunjukkan bahwa paling banyak responden merasa nyaman dan puas dengan gigi tiruan selama digunakan. Puas dengan warna gigi tiruan yang digunakan menandakan gigi tiruan mirip dengan gigi asli. $^{13}$

Penelitian mengenai persepsi responden berdasarkan ukuran gigi tiruan mendapatkan sebanyak 47 responden $(64,39 \%)$ merasa amat sangat setuju dengan ukuran gigi tiruanya dan 26 responden $(35,61 \%)$ sangat setuju (Tabel 7). Hal ini menunjukkan bahwa ukuran gigi tiruan dapat memengaruhi rasa percaya diri pasien pengguna gigi tiruan. Hal ini sejalan dengan hasil penelitian Zubaidah ${ }^{14}$ tentang perawatan estetik gigi anterior dengan kehilangan mahkota karena restorasi endo menunjukkan bahwa dengan melakukan perawatan, dapat mengembalikan rasa percaya diri pasien. ${ }^{14}$

Hasil persepsi kepuasan berdasarkan bentuk gigi tiruan memperlihatkan 46 responden $(63,01 \%)$ merasa amat sangat setuju, 26 responden $(35,61 \%)$ merasa sangat setuju dan 1 responden $(1,37 \%)$ merasa setuju (Tabel 8). Salah satu fungsi gigi tiruan yaitu mengembalikan fungsi estetik. Konsep estetik dalam bidang kedokteran gigi dapat membantu pasien mencapai rasa percaya diri yang sempat hilang karena hilangnya gigi depan. ${ }^{7,15}$ Hasil penelitian menunjukkan sebagian besar responden merasa sangat puas setiap kali menggunakan gigi tiruan dan merasakan perubahan penampilan yang lebih baik.

Hasil penelitian persepsi fungsi estetik dan fonetik berdasarkan susunan gigi tiruan mendapatkan sebanyak 48 responden $(65,75 \%)$ merasa sangat puas dan 25 responden $(34,24 \%)$ merasa puas (Tabel 9). Sebagian besar responden merasa sangat puas dengan gigi tiruannya. Susunan suatu gigi tiruan sangat penting terutama dalam fungsi estetik. Susunan gigi akan memengaruhi posisi bibir pengguna. ${ }^{4}$

Hasil penelitian berdasarkan penampilan gigi mendapatkan bahwa 41 responden $(56,16 \%)$ menjawab amat sangat setuju dan 32 responden $(43,83 \%)$ menjawab sangat setuju dengan penampilan pada gigi tiruan (Tabel 10). Hal ini menunjukkan tidak ada keluhan mengenai penampilan pada mulut responden.

Hasil penelitian persepsi berdasarkan pengucapan huruf (lidah dan gigi depan) mendapatkan bahwa sebanyak 52 responden $(71,23 \%)$ amat sangat setuju dan 21 responden $(28,76 \%)$ sangat setuju (Tabel 11). Berdasarkan hasil ini dapat diketahui sebagian besar responden percaya diri dan puas dengan penampilan memakai gigi tiruannya saat tersenyum. Responden yang puas dengan penampilan gigi tiruan menunjukkan fungsi estetik yang sempat hilang telah kembali berfungsi. ${ }^{15}$

Hasil penelitian persepsi fungsi estetik dan fonetik berdasarkan pengucapan huruf (lidah dan palatum) mendapatkan 23 responden $(31,50 \%)$ amat sangat setuju dan 50 responden $(68,50 \%)$ sangat setuju (Tabel 12). Sebagian besar responden merasa puas dengan pelafalan huruf yang diucapkan ketika memakai gigi tiruan.

Secara fungsional, gigi berperan penting dalam kehidupan sehari-hari. Kontak gigi memengaruhi kenyamanan dalam berkomunikasi, kontak gigi yang tidak tepat dapat mengganggu pengucapan. Penggunaan gigi tiruan yang baik akan membantu lansia melafalkan setiap huruf. ${ }^{8}$

Penilaian persepsi fungsi estetik dan fonetik berdasarkan pengucapan (bibir dan gigi depan) mendapatkan bahwa sebanyak 28 responden $(38,35 \%)$ merasa amat sangat setuju dan 45 responden $(61,64 \%)$ merasa sangat setuju dengan kontak bibir dan gigi depan (Tabel 13). Tidak dapat dipungkiri 
bahwa pelafalan merupakan faktor utama manusia berkomunikasi. Kehilangan gigi geligi mampu mengakibatkan berkurangnya kemampuan untuk melakukan aktivitas berbicara. ${ }^{16}$ Pada penelitian ini responden tidak merasa adanya keluhan setiap kali berbicara. Hal ini berarti fungsi fonetik yang pernah hilang mampu dikembalikan fungsinya dengan baik saat memakai gigi tiruan.

Penilaian persepsi fungsi estetik dan fonetik berdasarkan gangguan ketika berbicara mendapatkan sebanyak 47 responden $(64,39 \%)$ merasa amat sangat setuju dan 26 responden $(35,61 \%)$ merasa sangat setuju (Tabel 14). Tidak ada gangguan ketika berbicara menunjukan gigi tiruan yang digunakan dalam kategori baik dan layak.

Penilaian persepsi fungsi estetik dan fonetik berdasarkan pelafalan ketika berbicara mendapatkan sebanyak 48 responden $(65,75 \%)$ merasa amat sangat setuju dan 25 responden $(34,24 \%)$ merasa sangat setuju (Tabel 15). Tidak ada gangguan ketika berbicara menunjukkan gigi tiruan yang digunakan dalam kategori baik dan layak. Hal ini juga menunjukkan bahwa fungsi fonetik yang sempat hilang mampu dikembalikan.

Distribusi penilaian berdasarkan fungsi estetik menunjukkan skor rerata sebesar 335 (Tabel 16). Hal ini berarti komunitas lansia pada Gereja International Full Gospel Fellowship memiliki persepsi yang baik terhadap fungsi estetik.

Distribusi penilaian berdasarkan fungsi fonetik menunjukkan skor rerata sebesar 331 (Tabel 17). Hal ini berarti komunitas lansia pada Gereja International Full Gospel Fellowship memiliki persepsi yang baik terhadap fungsi fonetik.

\section{SIMPULAN}

Persepsi pengguna gigi tiruan terhadap fungsi estetik dan fungsi fonetik di komunitas lansia Gereja International Full Gospel Fellowship Manado berada dalam kategori baik.

\section{SARAN}

Diharapkan dapat dilakukan penelitian serupa dengan melibatkan responden yang lebih banyak agar dapat mewakili banyak populasi pengguna gigi tiruan lepasan.

Perlu dilakukan penelitian mengenai tingkat kepuasan lansia sebelum memakai gigi tiruan dan setelah menggunakan gigi tiruan, agar dapat diketahui harapan lansia sebelum memakai gigi tiruan dan persepsi lansia setelah memakai gigi tiruan.

\section{DAFTAR PUSTAKA}

1. Data Statistik Indonesia. Jumlah penduduk menurut kelompok umur, jenis kelamin, provinsi dan kabupaten/kota. Available from: https://demografi.bps.go.id/versi/ index.php?option=com_tabel\&task=\&itemi $\mathrm{d}=1$.

2. Mazlan KB. Tingkat kepuasan pasien lanjut usia pemakai gigi tiruan penuh berdasarkan sosiodemografi dan kondisi klinis rongga mulut [Skripsi]. Medan: Universitas Sumatera Utara; 2016.

3. Moulana A. Masih rendah kesadaran masyarakat terhadap kesehatan gigi dan mulut [Laporan seminar ilmiah Universitas Padjadjaran]. Available from: http://www.unpad. ac.id/2014/05/masih_ rendah_kesadaran_masyarakat_terhadap_ke sehatan_gigi_dan_mulut/. Universitas Padjajaran. 2014.

4. Al-Ghiferi FW. Gigi tiruan lengkap. [cited 2016 Jun 4]. Available from: https://id.scribd.com/doc/94133462/Gigi-

Tiruan-Lengkap.

5. Roessler DM. Complete denture success for patients and dentists. IDJ. 2003;53(5 suppl):340-5.

6. Yoanda W. Kegagalan adaptasi fonetik pada pasien pemakai gigi tiruan lepasan dan penanggulangannya [Skripsi]. Medan. Universitas Sumatera Utara; 2008.

7. Flores-Mir C, Silva E, Barriga MI, Valverde RH, Lagravere MO, Major PW. Lay persons' perception of the esthetics of visible anterior occlusion. J Can Dent Assoc. 2005;71(11):849-53.

8. Saldy A. Pengaruh estetik dan fonetik terhadap tingkat kepuasan pasien dalam menggunakan gigi tiruan sebagian lepasan di praktek dokter spesialis prostodonsia. Banda Aceh: Fakultas Kedokteran Gigi Universitas Syiah Kuala, 2010; p. 5-9. 
9. Agniti MD. Presentase penggunaan gigi tiruan di Indonesia. Media Litbang Kesehatan. 2010;20(2):50-8.

10. Sari DM. Karakteristik lansia penderita fraktur rawat inap di Rumah Sakit Haji Medan Tahun 2005-2009 [Skripsi]. Medan: Fakultas Kesehatan Masyarakat Universitas Sumatera Utara; 2011.

11. Sesaria I. Gigi tiruan lengkap (GTL). [cited 2017 Jan 29]. Available from: http://www.academia.edu/9706968/Gigi_Tir uan_Lengkap_GTL.

12. Panjaitan YP. Gambaran kemampuan mastikasi pada pasien pengguna gigi tiruan penuh di Rumah Sakit Gigi dan Mulut Universitas Sam Ratulangi Manado [Skripsi]. Manado: Universitas Sam Ratulangi; 2016.

13. Naibaho N. Penyesuaian oklusal gigi geligi sebelum pembuatan gigi tiruan [Skripsi]. Medan: Fakultas Kedokteran Gigi Universitas Sumatera Utara; 2008.

14. Zubaidah N. Perawatan estetik gigi anterior dan kehilangan mahkota karena restorasi endo. Surabaya: Universitas Airlangga; 2014.

15. Syarfita PD. Pertimbangan yang mendasari segi estetik pada tumpatan komposit gigi anterior [Skripsi]. Medan: Universitas Sumatera Utara; 2008.

16. McMillan AS. Emotional effects of tooth loss in community-dwelling elderly people in Hongkong. US National Library of Medicine National Institutes of Health. [cited 2017 Jan 30]. Available from: http://www.ncbi.nlm.nih.gou/pubmed/15119 867. 